\title{
Undersown cover crops have limited weed suppression potential when reducing tillage intensity in organically grown cereals
}

\author{
J. Salonen $(1)$ E. Ketoja
}

Received: 19 November 2018 / Accepted: 22 July 2019 /Published online: 14 August 2019

C) The Author(s) 2019, corrected publication 2019

\begin{abstract}
Adoption of reduced tillage in organic cropping has been slow, partly due to concerns about increasing weed infestation. Undersown cover crops (CCs) are considered to be a feasible option for weed management but their potential for weed suppression is insufficiently investigated in low-till organic cropping. The possibilities to reduce primary tillage by introducing CCs to maintain weed infestation at a level that does not substantially jeopardize crop yield were studied in a field experiment in southern Finland during 2015-2017. Eight different CC mixtures were undersown in cereals and the response in weed occurrence was consecutively assessed in spring barley, winter wheat, and finally, as a subsequent effect, in spring wheat. Growth of CCs was too slow to prevent the flush of early emerging weeds in spring barley whereas in winter wheat, CCs succeeded in hindering the growth of weeds. However, CCs could not prevent the increase of perennial weeds in a reduced tillage system in which the early growth of spring wheat was retarded in cool 2017. Consequently, after 2 years of reduced tillage, weed biomass was about 2.6 times higher and spring wheat yield was $30 \%$ lower than in plowed plots, respectively. No major differences in weed control efficacy among CC treatments were evident. A grain yield benefit was recorded after repeated use of leguminous CCs. The need for long-term field studies remains of particular interest regarding post-
\end{abstract}

J. Salonen $(\bowtie) \cdot$ E. Ketoja

Natural Resources Institute Finland (Luke), FI-31600 Jokioinen, Finland

e-mail: jukka.salonen@1uke.fi harvest performance and influence of CCs on perennial weeds before the inversion tillage.

Keywords Cereals · Cover crops · Organic farming · Reduced tillage $\cdot$ Weeds $\cdot$ Weed management

\section{Introduction}

Weed management in organic production aims at maintaining the weed infestation at an acceptable level, balancing the detrimental effects against the beneficial aspects (Turner et al. 2007). Organic production relies both on indirect cultural control methods and direct means to control weeds (Kolb and Gallandt 2012). In addition to being a general crop management practice, tillage is considered to be a key measure for weed management (Håkansson 2003; Armengot et al. 2016). Recently, the TILMAN-ORG project explored reduced tillage and green manures, aiming to design improved organic cropping systems with enhanced productivity and nutrient use efficiency, more efficient weed management, and increased biodiversity (see: www.tilman-org.net). The study presented in this paper was part of the CORE Organic Plus project "Crop diversification and weeds, PRODIVA” (Melander 2018).

Intensive inversion tillage is commonly used by farmers to manage weeds in organic cereal production (Peigne et al. 2007). Primary tillage, by plowing the soil to a depth of $20-25 \mathrm{~cm}$, is used to manage weeds, particularly perennial weed species (Gruber 
and Claupein 2009; Melander et al. 2013). In Finland, moldboard plowing in autumn has been a common practice, particularly in southern Finland where heavy clay is the predominant soil type (Luke 2019). With the aim of saving time and fuel in cropping operations, reduced tillage has become more common, primarily in conventional cropping (Salonen et al. 2012). Conservation tillage would bring economic benefits to organic cropping and support the common aim of preserving soil quality and fertility (Peigne et al. 2007, Casagrande et al. 2016; Zikeli and Gruber 2017). However, replacing plowing with reduced tillage causes reasonable concerns regarding disease and weed management (Andert et al. 2016; Scherner et al. 2016) and maintaining crop yields (Cooper et al. 2016).

Cover crops (CCs) have been studied as a potential targeted combination with reduced tillage to overcome the expected drawbacks in weed management (Brandsæter et al. 2012; Dorn et al. 2015). In the past, the potential of undersown catch crops to minimize nitrogen leaching was investigated under northern conditions (e.g., Askegaard et al. 2005; Aronsson et al. 2015), but the occurrence of weeds often played a minor role in the assessments (Salonen et al. 2017). Therefore, further studies with a wide selection of feasible CC species of differing competitive abilities against weeds are warranted, particularly in organic cropping systems (Dorn et al. 2015).

Applying undersown CCs for weed management in cereal crops includes various strategies in terms of time of sowing, duration of cover crop growth, and way of termination (Brandsæter et al. 2012; Bergkvist et al. 2010; Carr et al. 2013; Dorn et al. 2015). CCs can be undersown (i) at the same time as spring cereals, (ii) combined with weed harrowing in early summer, or (iii) broadcast later into the crop stand if the main purpose is to catch nutrients in autumn rather than to suppress weeds (Salonen et al. 2017; Verret et al. 2017). When CCs are sown after crop harvest to reduce leaching of nutrients, they are often called catch crops (Salonen et al. 2017). Furthermore, when left undisturbed over the winter, cover or catch crop mulch residues suppress weed growth, both in late autumn and in early spring before seedbed preparation and sowing (Kruidhof et al. 2007; Dorn et al. 2015). In addition to physical weed suppression, some CCs can inhibit weed growth via allelopathy (Reiss et al. 2018; Sturm et al. 2018).
In the present study, CCs were undersown in spring barley and winter wheat in early spring to obtain information about their weed suppression potential in organically grown cereals. It was hypothesized that satisfactory weed control can be achieved with tailored CC mixtures. Because CCs were undersown in the main crop at the very beginning of the growing season, their influence on crop yields was also of interest. Based on earlier studies (Ohlander et al. 1996), we did not expect early sown CCs to cause substantial crop yield losses. However, the effect of CCs on organic grain yield depends on cereal and CC species, soil type, crop rotation, and the application of $\mathrm{N}$ in manure (Olesen et al. 2007; Doltra and Olesen 2013). By growing both leguminous and non-leguminous CCs, we expected to observe some long-term response to available nitrogen, both in weed infestation and crop yields.

We aimed also to investigate the possibility to reduce tillage intensity in organically cropped cereals by managing the expected increase in weed pressure with competitive undersown CCs. More information is needed on weed dynamics in organic reduced tillage systems to support interested growers in decision-making. For this purpose, CC mixtures with relatively high seeding rates were designed and studied both in organic spring barley and winter wheat in order to generate cropping recommendations for CCs adjusted to northern conditions. A 3-year field experiment was carried out to investigate the responses in weed populations when conventional plowing (PL) was replaced with reduced tillage (RT). The experiment continued for three consecutive years and was conducted following the principles of organic cropping, without addition of any synthetic agrichemicals.

By monitoring the weeds over the 3 years, we expected to observe some changes in weed populations according to tillage practices and different CC treatments, both in terms of species composition, abundance, and potential of CCs to remain as volunteer weeds. The effects of CC treatments within the main crop were observed during the first two growing seasons whereas the comparison of tillage practices was based on observations made during the last two experimental years.

In brief, the main objective of the field experiment was to investigate to what extent the competition of CCs can prevent weed growth, in particular the expected increase of weed infestation, when plowing is replaced with reduced tillage. 


\section{Materials and methods}

Cover crop treatments

A wide range of $\mathrm{CC}$ species, mainly in mixtures, were undersown in cereals to assist the main crop in competition against weeds. Eight different $\mathrm{CC}$ treatments were included and compared with treatment without CCs (Table 1). Most of the CC mixtures included leguminous species for nitrogen supply in the rotation, except one treatment (C5), which was solely non-legume monocotyledonous: rye (Secale cereale L.) in 2015 followed by Italian ryegrass (Lolium multiflorum Lam.) in the same plots in 2016.

Field experiment

A field experiment with CCs in cereals was carried out in Jokioinen, Southwest Finland $\left(60^{\circ} 49^{\prime} \mathrm{N}, 23^{\circ} 29^{\prime} \mathrm{E}\right.$, WGS84) during 2015-2017. The experiment had a strip-plot design (Gomez and Gomez 1984) in which the field plots were arranged in four rectangular blocks (Fig. 1).

The experimental field went through a transient period from conventional to organic cropping during 2013-2014. The main crop in 2013 was spring oat (Avena sativa L.) with an undersown clover-grass mixture (Trifolium pratense L., T. repens L., Festuca pratensis Hud., Phleum pratense L.), which was grown as a green manure grass-clover mixture in 2014. The experimental area was plowed to a depth of $25 \mathrm{~cm}$ in November 2014. The soil type was sandy clay (clay content 57\%) with an average $\mathrm{pH}$ of 5.6. No fertilizers were applied during the whole period of 2013-2017.

The crop rotation during the years of experimentation (2015-2017) was spring barley-winter wheat-spring wheat (Table 2). CC treatments C2-C6 and C8-C9 were undersown in spring barley (Hordeum vulgare L., cultivar "Wolmari") in May 2015 and in winter wheat (Triticum aestivum L., cultivar "Urho") in early

Table 1 Cover crop treatments in the field experiments in Jokioinen during 2015-2016

\begin{tabular}{|c|c|c|c|c|c|}
\hline Treatment & Plant species & Cultivar & Latin names & Code $^{a}$ & Seed rate, $\mathrm{kg} \mathrm{ha}^{-1}$ \\
\hline $\mathrm{C} 1$ & No cover crops & - & - & - & 0 \\
\hline \multicolumn{6}{|c|}{ Non-legumes } \\
\hline \multirow[t]{2}{*}{$\mathrm{C} 5$} & Winter rye (2015) & Reetta & Secale cereale L. & SECCE & 100 \\
\hline & It. ryegrass (2016) & Teanna & Lolium multiflorum Lam. & LOLMU & 8 \\
\hline \multicolumn{6}{|l|}{ Mixed } \\
\hline \multirow[t]{2}{*}{ C6 } & Black medic & Virgo & Medicago lupulina $\mathrm{L}$. & MEDLU & 20 \\
\hline & Italian ryegrass & Teanna & Lolium multiflorum Lam. & LOLMU & 8 \\
\hline \multicolumn{6}{|l|}{ Legumes } \\
\hline \multirow[t]{2}{*}{$\mathrm{C} 2$} & Red clover & Ilte & Trifolium pratense $\mathrm{L}$. & TRFPR & 8 \\
\hline & White clover & Sonja & Trifolium repens $\mathrm{L}$. & TRFRE & 4 \\
\hline \multirow[t]{4}{*}{$\mathrm{C} 3$} & Black medic & Virgo & Medicago lupulina $\mathrm{L}$. & MEDLU & 6 \\
\hline & Crimson clover & Contea & Trifolium incarnatum L. & TRFIN & 4 \\
\hline & Persian clover & Lightning & Trifolium resupinatum $\mathrm{L}$. & TRFRM & 3 \\
\hline & White clover & Huia & Trifolium repens L. & TRFRE & 2 \\
\hline \multirow[t]{2}{*}{$\mathrm{C} 4$} & Red clover & Ilte & Trifolium pratense $\mathrm{L}$. & TRFPR & 12 \\
\hline & White clover & Sonja & Trifolium repens $\mathrm{L}$. & TRFRE & 6 \\
\hline \multirow[t]{3}{*}{$\mathrm{C} 7^{\mathrm{b}}$} & Common vetch & Ebena & Vicia sativa $\mathrm{L}$. & VICSA & 40 \\
\hline & Oilseed radish & Karakter & Raphanus sativus L. & RAPRA & 5 \\
\hline & Westerwold ryegrass & DE-14 & Lolium multifl. var. $W W$ & LOLMU & 5 \\
\hline \multirow[t]{3}{*}{$\mathrm{C} 8^{\mathrm{b}}$} & Black medic & Virgo & Medicago lupulina $\mathrm{L}$. & MEDLU & 5 \\
\hline & White clover & Sonja & Trifolium repens $\mathrm{L}$. & TRFRE & 1 \\
\hline & White sweet clover & Kuusiku & Melilotus alba Med. & MEUAL & 4 \\
\hline \multirow[t]{3}{*}{$\mathrm{C} 9^{\mathrm{b}}$} & Black medic & Virgo & Medicago lupulina $\mathrm{L}$. & MEDLU & 10 \\
\hline & White clover & Sonja & Trifolium repens $\mathrm{L}$. & TRFRE & 2 \\
\hline & White sweet clover & Kuusiku & Melilotus alba Med. & MEUAL & 8 \\
\hline
\end{tabular}

a EPPO code available at: https://gd.eppo.int/

b Late-sown catch crops primarily to prevent nutrient leaching; sown as three-species mixture in $\mathrm{C} 7$ and as additional catch crops in C8 (VICSA, $40 \mathrm{~kg} \mathrm{ha}^{-1}$ ) and in C9 (RAPRA, $15 \mathrm{~kg} \mathrm{ha}^{-1}$ and LOLMU var. WW, $15 \mathrm{~kg} \mathrm{ha}^{-1}$ ) 
Fig. 1 Schematic illustration of the first block in a strip-plot design. Each block consisted of two rows (horizontal strips) and nine columns (vertical strips running perpendicular to the rows). Two tillage systems $(\mathrm{RT}=$ reduced, $\mathrm{PL}=$ plowed) were randomly assigned to the rows (all of the plots within each row) and nine cover crop treatments $(\mathrm{C} 1-\mathrm{C} 9)$ to the columns in the four blocks, separately and independently

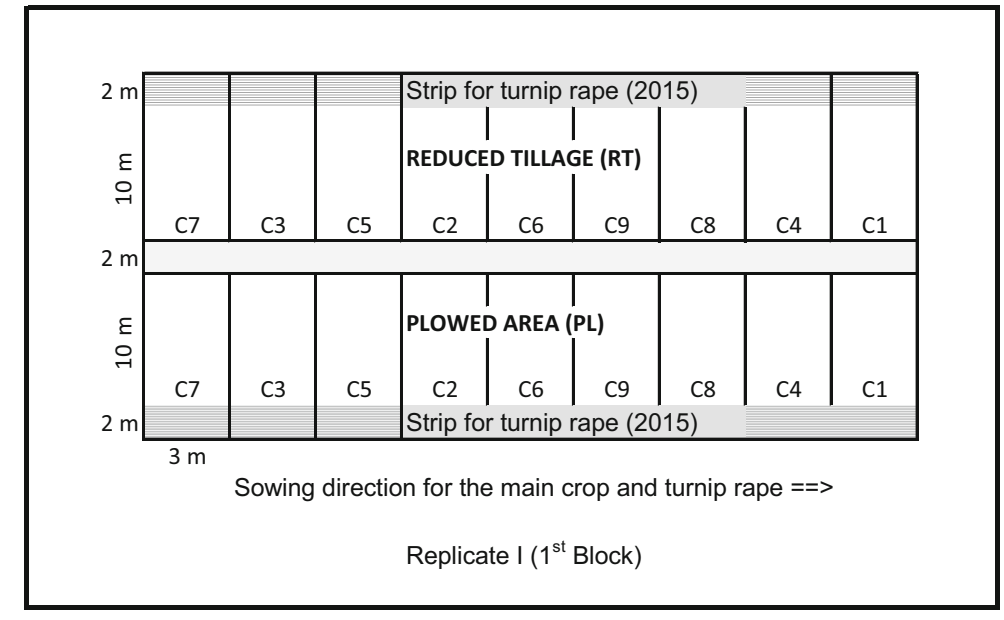

May 2016. In addition, treatments C7-C9 included latesown catch crops that were broadcast on the ground in barley stands in early July 2015 and shallowly directdrilled in stubble after winter wheat harvest in 2016 with the aim to catch nitrogen for the next crop (Askegaard et al. 2005). In 2017, no further CCs were sown in spring wheat (Triticum aestivum L., cultivar "Anniina") in order to assess the subsequent effect of CCs and tillage on weed occurrence and crop yield. The weather conditions varied between the cropping seasons particularly in early summer when 2016 was warmer and dryer than 2015 and 2017 (Tables 3 and 4).
Cereal crops were sown with a farm-size $2.5 \mathrm{~m}$ wide sowing machine at a standard row space of $12.5 \mathrm{~cm}$, placing seeds at a depth of 5-6 cm. Recommended seed rates for organic production were applied (Table 2). CCs were thereafter sown across the cereal rows 1 day after sowing spring barley (2015) and at early tillering stage (BBCH 21) of winter wheat in early May 2016. The $1.5-\mathrm{m}$ wide Wintersteiger plot seeder was equipped with disc coulters that placed the cover crop seeds at a depth of 1-2 cm with $12.5 \mathrm{~cm}$ row space. The plot size was $3 \mathrm{~m} \times 10 \mathrm{~m}$ (Fig. 1).

In 2015, spring turnip rape (Brassica rapa L. ssp. oleifera, BRSRO) was sown as a "supplemental weed"

Table 2 Crops and cropping operations in the experimental field in Jokioinen

\begin{tabular}{|c|c|c|c|}
\hline \multirow[t]{2}{*}{ Cropping information } & \multicolumn{3}{|c|}{ Year and dates } \\
\hline & 2015 & 2016 & 2017 \\
\hline Crop & S. Barley & W. Wheat & S. Wheat \\
\hline Cultivar & Wolmari & Urho & Anniina \\
\hline Sowing density, crop seeds $\mathrm{m}^{-2}$ & 500 & 550 & 650 \\
\hline Sowing, crop & 21-May-15 & 14-Sep-15 & 22-May-17 \\
\hline Sowing, cover crops & 22-May-15 & 06-May-16 & Not sown \\
\hline Sowing, late-sown catch crops & 06-Jul-15 & 25-Aug-16 & Not sown \\
\hline Crop emergence (1-2 leaves) & 01-Jun-15 & 28-Sep-15 & 02-Jun-17 \\
\hline Crop heading & 09-Jul-15 & 17-Jun-16 & 20-Jul-17 \\
\hline Plant sampling & 21-Aug-15 & 15-Aug-16 & 16-Aug-17 \\
\hline Crop harvest & 31-Aug-15 & 24-Aug-16 & 26-Sep-17 \\
\hline Primary tillage, disc harrow & 07-Sep-15 & 12-Oct-16 & 03-Nov-17 \\
\hline Primary tillage, plow & 08-Sep-15 & 19-Oct-16 & 03-Nov-17 \\
\hline
\end{tabular}


Table 3 Weather data from Jokioinen during the growing seasons 2015-2017. Source: Finnish Meteorological Institute

\begin{tabular}{|c|c|c|c|c|c|c|}
\hline $\begin{array}{l}\text { Year } \\
\text { Month }\end{array}$ & & $\begin{array}{l}\text { Temperature } \\
{ }^{\circ} \mathrm{C}\end{array}$ & & & $\begin{array}{l}\text { Precipitation } \\
\mathrm{mm}\end{array}$ & \\
\hline & Min & Max & Mean & L-t mean ${ }^{\mathrm{a}}$ & Sum & L-t mean ${ }^{a}$ \\
\hline \multicolumn{7}{|l|}{2015} \\
\hline May & -3.6 & 17.6 & 8.9 & 9.8 & 49.4 & 41.0 \\
\hline Jun & 2.3 & 22.5 & 12.4 & 14.0 & 87.6 & 63.0 \\
\hline Jul & 6.8 & 28.3 & 15.1 & 16.7 & 74.7 & 75.0 \\
\hline Aug & 4.1 & 25.7 & 15.8 & 15.0 & 45.8 & 80.0 \\
\hline Sep & 1.7 & 19.2 & 11.5 & 9.9 & 47.4 & 58.0 \\
\hline \multicolumn{7}{|l|}{2016} \\
\hline May & -0.4 & 26.0 & 12.8 & 9.8 & 31.1 & 41.0 \\
\hline Jun & 1.1 & 27.0 & 14.7 & 14.0 & 74.4 & 63.0 \\
\hline Jul & 7.3 & 25.1 & 16.8 & 16.7 & 56.8 & 75.0 \\
\hline Aug & 3.8 & 23.8 & 15.0 & 15.0 & 71.8 & 80.0 \\
\hline Sep & -1.2 & 22.1 & 11.5 & 9.9 & 40.3 & 58.0 \\
\hline \multicolumn{7}{|l|}{2017} \\
\hline May & -4.6 & 25.3 & 8.9 & 9.8 & 13.4 & 41.0 \\
\hline Jun & 1.4 & 23.4 & 12.8 & 14.0 & 101.4 & 63.0 \\
\hline Jul & 4.2 & 23.3 & 14.9 & 16.7 & 44.7 & 75.0 \\
\hline Aug & 2.4 & 22.8 & 14.6 & 15.0 & 93.6 & 80.0 \\
\hline Sep & 0.3 & 18.1 & 10.4 & 9.9 & 41.8 & 58.0 \\
\hline
\end{tabular}

${ }^{\text {a }}$ Long-term monthly mean 1981-2010

in order to guarantee an adequate infestation of weeds in spring barley. The area for turnip rape, sown with a 2.0 $\mathrm{m}$ wide sowing machine on the same day and in the same direction as spring barley, was $2.0 \mathrm{~m} \times 3.0 \mathrm{~m}$ at one end of each $10 \mathrm{~m}$ trial plot (Fig. 1).

Table 4 Effective temperature sum accumulation (day degrees, base $+5{ }^{\circ} \mathrm{C}$ ) and precipitation sum between the experimental operations in Jokioinen during 2015-2017. Source: Finnish Meteorological Institute

\begin{tabular}{lll}
\hline $\begin{array}{l}\text { Year } \\
\text { Operations }\end{array}$ & $\begin{array}{l}\text { Temperature } \\
\text { DD },{ }^{\circ} \mathrm{C}\end{array}$ & $\begin{array}{l}\text { Precipitation } \\
\mathrm{mm}\end{array}$ \\
\hline 2015 & & \\
Sowing_Weed Sampling & 823 & 184 \\
Sowing_Crop Harvest & 928 & 215 \\
2016 & & \\
Sowing_Weed Sampling & \\
Sowing_Crop Harvest $^{\mathrm{a}}$ & 1015 & 210 \\
2017 & 1108 & 292 \\
Sowing_Weed Sampling & 779 & 222 \\
Sowing_Crop Harvest & 1050 & 228 \\
\hline
\end{tabular}

${ }^{\text {a }}$ From the beginning of growing season 2016
After the first crop, spring barley with undersown CCs, the experimental areas (horizontal strips) were either plowed (PL) to a depth of $25 \mathrm{~cm}$ or cultivated with a heavy disc harrow (RT) to a depth of $10 \mathrm{~cm}$ in early September 2015 before sowing winter wheat. Similar tillage operations were repeated in October 2016 after the winter wheat harvest (Table 2).

Sampling and measurements

The plant densities of CCs and weeds were determined by counting the plants or shoots, by species, from two randomly placed frames in each plot so that the other sample was taken from the strip where turnip rape was sown in 2015. From the same plots, the number of crop ears was counted in 2015 and 2016. A rectangular frame measuring $0.1 \mathrm{~m}^{2}(25 \mathrm{~cm} \times 40 \mathrm{~cm})$ was used. Plant samples were taken by cutting the plants at ground level in mid-August before harvesting the cereal crop. The air-dry biomass of all plants, including crops, was weighed by species after the samples had been dried in an air-flow dryer at $40{ }^{\circ} \mathrm{C}$ until reaching constant weight. The results are presented as dry weight per 
square meter $\left(\mathrm{m}^{2}\right)$. In 2015, CC treatments C7-C9 were not assessed because the late-sown $\mathrm{CC}$ treatments failed to germinate and the original protocol could not be followed.

The crop cover (\%) was assessed in late May 2016 to describe the overwintering of winter wheat. The grain yield was determined by harvesting cereals from areas measuring $14 \mathrm{~m}^{2}$ in 2015 and $21 \mathrm{~m}^{2}$ in 2016 and 2017. Harvested material was dried, threshed, and weighed. Grain yields are reported with a standardized moisture content of $15 \%$.

\section{Statistical analyses}

The data for 2015, 2016, and 2017 were analyzed separately using linear mixed models for Gaussian and nonGaussian data (Gbur et al. 2012). In 2015, also the data for natural weeds and supplemental weed oilseed turnip rape (Weeds + BRSRO) were analyzed separately from the data for natural weeds because of differences in magnitude and variation in the observations. Further, in 2015, the effect of tillage system was not relevant because the tillage operations (PL, RT) were performed only after the first crop in September. Therefore, means of the measurements from the two tillage plots were calculated for each response variable (weed density, weed biomass, grain yield) and used as data in statistical analyses. Consequently, the response variables could be analyzed as Gaussian-distributed variables using linear mixed models, where the effect of $\mathrm{CC}$ was a fixed effect and the effect of block was a random effect besides a random experimental error term.

In 2016 and 2017, grain yield was also approximately Gaussian-distributed and was analyzed according to the linear mixed model for a strip-plot design (Gomez and Gomez 1984), including three fixed effects (main effects of tillage system and $\mathrm{CC}$ and their interaction) and four random effects (the block effect and three error terms associated with the rows, the columns, and the intersection of a row and a column). Furthermore, in 2016, winter wheat cover (\%) assessed in late May was added as a covariate variable to the model because crop cover varied distinctly from plot to plot and was linearly related to grain yield. The inclusion of the covariate variable enabled comparison of the treatments at an equal crop cover (mean of crop cover in the data), and consequently, the differences in crop cover among the treatments were eliminated from their comparisons. The models for the Gaussian-distributed variables were fitted using the restricted maximum likelihood (REML) approach (Gbur et al. 2012). The statistical significances of the fixed effects of the models were determined through $F$ tests, approximating degrees of freedom using the Kenward-Roger method (Kenward and Roger 1997). Estimated means for the response variables and standard errors of means (SEMs) were determined on the basis of the models and the preplanned comparisons of the means were made using two-sided $t$-type tests (Gbur et al. 2012). The Gaussian assumption was checked through the studentized residuals using boxplots, and the constancy of the variance by plotting the studentized residuals against the fitted values (Gbur et al. 2012). The statistical analyses were implemented using the MIXED procedure of SAS/ STAT software (version 14.2; SAS Institute 2016).

Weed density and biomass were not Gaussiandistributed in 2016 and 2017 and were therefore analyzed according to the generalized linear mixed model for a strip-plot design (Gbur et al. 2012). Weed biomass was analyzed as a Gamma-distributed variable and its model had the logarithmic link function and the same fixed and random effects as the model for yield in 20162017, plus winter wheat cover as a covariate in 2016. For weed density, the negative binomial distribution with the logarithmic link function adequately fitted the data. The covariate variable was omitted from the model in 2016 due to absence of a relationship between weed density and crop cover. The models were fitted using a pseudo-likelihood approach, and hypothesis testing of the fixed effects was performed through Wald $F$ tests and $t$ tests, calculating degrees of freedom using the Kenward-Roger method (Gbur et al. 2012). Statistical testing and estimation were performed on the log scale, but the estimated means were converted back to the data scale by applying the exponential function, while the standard errors of the means (SEMs) were obtained using the Delta method (Gbur et al. 2012).

Systematic departures from the models were assessed by plotting studentized residuals against the linear predictor and the adequacy of the log link function was checked by plotting log-transformed values of the response variables against the linear predictor (Gbur et al. 2012). The modelling was performed using the GLIMMIX procedure of SAS/STAT software (version 14.2; SAS Institute 2016). Patchiness of perennial weed species, such as Cirsium arvense L., Ranunculus repens L., and Sonchus arvensis L., resulted in a few outliers and consequently high variation in the weed biomass 
data. However, removing the outliers had no essential effect on results and their interpretation and therefore the results based on all data are presented in this paper.

Differences in the weed species diversity between two tillage practices were determined by calculating Shannon's and Simpson's indices for the proportional weed biomass pooled over CC treatments in 2017 (Magurran 1988).

\section{Results}

Cover crop growth

Spring barley reached the 1-2 leaf growth stage within 10-12 days in early June 2015, while CCs emerged about 1 week later, thus resulting in a competitive advantage for the crop. Winter wheat, sown in September 2015, gained an even greater lead over the CCs that were sown in early May 2016 when the wheat stand was already beginning to tiller (BBCH 21). Nevertheless, $\mathrm{CCs}$ had relatively good conditions for emergence and early growth in a sparse wheat stand with the average crop cover of $44 \%$ in late May.

Additional catch crops, sown in treatments C7-C9 (Table 1), failed to germinate and grow properly both in spring barley in 2015 and after winter wheat harvest in an extremely dry September in 2016. Therefore, the results for $\mathrm{C} 7$ are not presented and the $\mathrm{CC}$ effects in $\mathrm{C} 8$ and $\mathrm{C} 9$ derive primarily from their spring-sown $\mathrm{CCs}$ (Table 1).

The biomass production of $\mathrm{CC}$ mixtures differed substantially among treatments and years (Fig. 2). In spring barley in areas with natural weeds, the average dry weight biomass of CCs in August 2015 ranged from $58 \mathrm{~g} \mathrm{~m}^{-2}$ (C2) to $134 \mathrm{~g} \mathrm{~m}^{-2}$ (C6). Both Italian ryegrass (Lolium multiflorum L.) in C6 and spring-sown rye (Secale cereale L.) in C5 thrived in spring barley in 2015 , producing $15 \%$ of the total dry weight biomass of sown crops (cereal + cover crop). The proportion of leguminous CCs ranged from $9 \%(\mathrm{C} 2)$ to $14 \%(\mathrm{C} 3, \mathrm{C} 4)$. In all, Persian clover (Trifolium resupinatum $\mathrm{L}$.) was the most vigorous clover species followed by red clover, crimson clover (T. incarnatum L.), and white clover.

During summer 2016, the biomass production of Italian ryegrass was poor, averaging only $10 \mathrm{~g} \mathrm{~m}^{-2}$ (C5) and being considerably lower than the average dry weight biomass of CCs in other treatments, which ranged from $100 \mathrm{~g} \mathrm{~m}^{-2}$ (C6) to $169 \mathrm{~g} \mathrm{~m}^{-2}$ (C4, Fig. 2b).
The share of CCs out of the total biomass of sown crops ranged from $3 \%(\mathrm{C} 5)$ to $19 \%$ (C2, C9), without any major difference between tillage systems. Black medic (Medicago lupulina L.) was the most vigorous $\mathrm{CC}$ in plowed plots (PL) followed by red clover and white clover. Red clover produced the highest fraction of CC biomass in reduced tillage (RT), partly because of residual plants from 2014 and 2015.

In 2017, the biomass of residual CCs was negligible, except that of white sweet clover (Melilotus alba L.) in C8 and C9 treatments in RT (Fig. 2c). Regarding other $\mathrm{CCs}$, white clover was the most abundant residual CC species in PL as well in RT, where also red clover and Italian ryegrass remained in small numbers.

Weed infestation

The previous crop rotation in the experimental field had been typical for animal husbandry farms, with a relatively high proportion of rotational grassland over the years. The majority of weed species were annual dicots and no tall-growing perennials were abundant in 2015. The share of weeds of the total above-ground biomass (crop + weeds) in C1 plots (no CCs) was 3\% in 2015, increased to $11 \%$ in RT and $16 \%$ in PL in 2016, and was finally $11 \%$ in RT and 3\% in PL in 2017.

Overall, an increasing weed infestation was recorded after 2 years with RT (Fig. 3g, Tables 5 and 6). However, a contradictory result was achieved in 2016 when annual weed species were still predominant and the weed biomass in RT winter wheat was $42 \%$ lower than that in PL (Table 6).

In 2015, the most abundant weed species in spring barley were Galeopsis L. spp., Myosotis arvensis (L.) Hill, Stellaria media (L.) Vill., Viola arvensis Murr., and Taraxacum Weber spp. The overall mean total density of natural weeds was $126 \pm 19$ plants $\mathrm{m}^{-2}$, mainly consisting of broad-leaved annuals, $M$. arvensis being the most abundant species. CC treatments did not have any significant effect on the weed density (Fig. 3a, Table 5). The total weed biomass in $\mathrm{C} 1$, on average $17 \pm 2.9 \mathrm{~g} \mathrm{~m}^{-2}$ in areas with natural weeds, was not significantly different from any CC treatment (Fig. 3b).

In addition to natural weeds, the weed infestation in turnip rape strips consisted of considerable numbers of turnip rape plants (supplemental weed), about 300 plants $\mathrm{m}^{-2}$ on average. By sowing turnip rape as supplemental weed in the plots in 2015, we succeeded in increasing the weed abundance substantially 


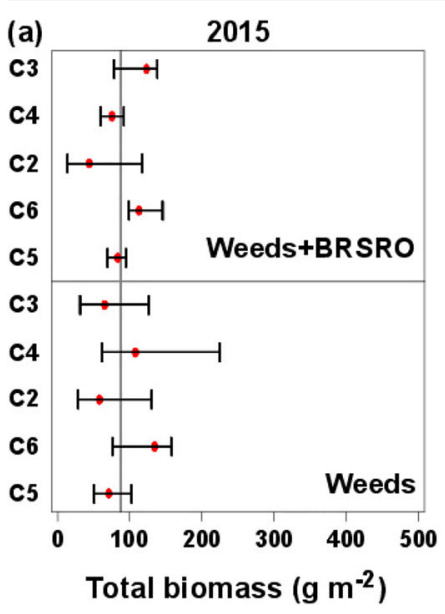

Fig. 2 Medians (dots) with minimum and maximum values (bars) for the total dry weight biomass of cover crops (C2-C9, see Table 1) during 2015-2017. In 2015 (a), the cover crop biomass was assessed both from areas with natural weed infestation

(Fig. 3a, b). Neither the turnip rape density nor its biomass, on average $73 \pm 4.8 \mathrm{~g} \mathrm{DM} \mathrm{m}^{-2}$, was significantly suppressed by CC treatments (Fig. 3a, b, Table 5).

The total weed density averaged across the $\mathrm{CC}$ treatments in winter wheat in 2016 was at the same level in both tillage systems, $182 \pm 17$ plants $\mathrm{m}^{-2}$ in RT and 164 \pm 16 plants $\mathrm{m}^{-2}$ in PL (Fig. $3 \mathrm{~d}$ ), in contrast to the more pronounced difference between the tillage systems in weed biomass (Table 6). Typical overwintering species Tripleurospermum inodorum Sch.Bip., M. arvensis, and $S$. media were the most abundant species. In contrast to the less satisfactory results in spring barley, weed density was significantly reduced with CC treatments in winter wheat in 2016 irrespective of the tillage treatment (Table 5). Except for C5 with Italian ryegrass, CC treatments significantly reduced the total weed density compared to $301 \pm 55$ plants $\mathrm{m}^{-2}$ in $\mathrm{C} 1$, which was $108 \%$ higher than the average density in the plots with CCs (Fig. 3d).

In 2016, weed biomass in standard clover mixture (C2) was 55\% lower than in non-CC treatment (C1) and even $70 \%$ lower in the same CC mixture with $50 \%$ higher $\mathrm{CC}$ seed rate $(\mathrm{C} 4)$, respectively (Fig. 3e). The satisfactory outcome was to some extent explained by residual clover plants originating from earlier years. In contrast, Italian ryegrass grew poorly and the weed biomass in C5 was $161 \%$ higher compared with other $\mathrm{CC}$ treatments in RT and 22\% higher in PL. The most abundant weeds affected by CCs in winter wheat were T. inodorum and M. arvensis.
In 2017, after 2 years with reduced primary autumn tillage, the weed density in spring wheat averaged $789 \pm$ 133 plants $\mathrm{m}^{-2}$ in RT and $268 \pm 45$ plants $\mathrm{m}^{-2}$ in PL (Table 5, Fig. $3 \mathrm{~g}$ ). The total weed density in RT was even higher because individual plants of $S$. media could not be counted in the dense infestation of plants at various growth stages. CC treatments during 20152016 did not have any statistically significant subsequent effect on weed density in 2017 (Table 5). Similarly, the total weed biomass in RT was considerably higher than in PL and especially in the CC treatments (C5, C6) which had included grass species (Fig. 3h, Table 6). The predominant annual weed species in both tillage systems were $S$. media and $M$. arvensis complemented with Trifolium plants as volunteer weeds. The share of perennial weed species was 53\% out of the total weed biomass in RT whereas it was only $35 \%$ in PL (Fig. 4). Cirsium arvense was the most abundant perennial weed, corresponding almost to $40 \%$ of the total weed biomass production in RT and $21 \%$ in PL. There were more grass species shoots in RT but their relative abundance was higher in PL in terms of biomass share (Fig. 4). The main grass species were residual crops (Festuca pratensis, Lolium multiflorum, and Phleum pratense) and weeds (mainly Poa annua L.)

Weed species shift

In the first year of experimentation, 2015, 26 weed species were determined from the sampled areas. Two 


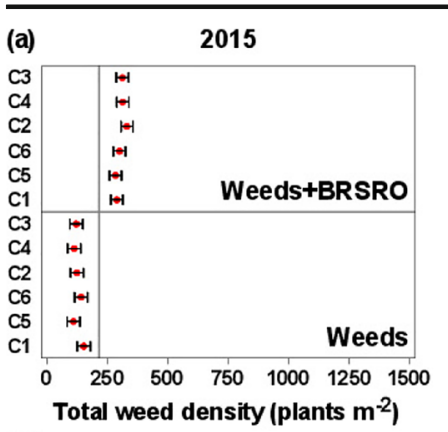

(b)

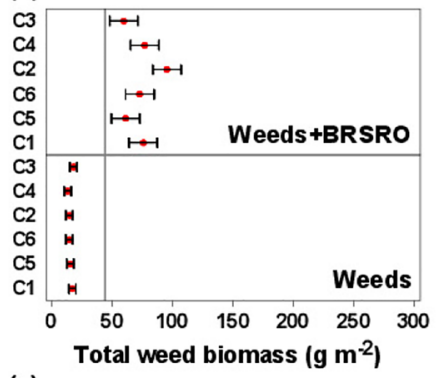

(c)

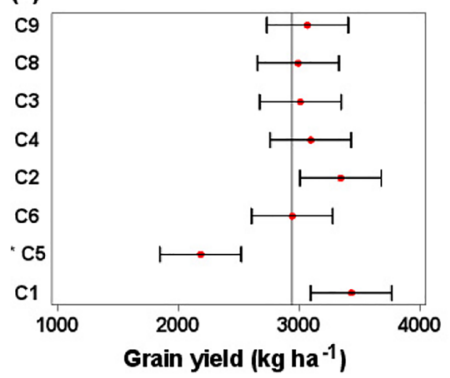

Fig. 3 Effect of cover crop treatment (C1-C9, see Table 1) and tillage system $(\mathrm{PL}=$ plowed, $\mathrm{RT}=$ reduced $)$ on weed abundance and grain yield during 2015-2017. Estimated means (dots) are shown \pm standard errors of means (bars). In 2015 (a-c), the weed abundance was measured both from areas with natural weeds (Weeds) and from areas with natural weeds and additionally sown oilseed weed (Weeds + BRSRO). The grain yield in 2015 is from

years later, the total number of recorded weeds was 33 species in RT and 29 species in PL. Capsella bursapastoris (L.) Medic., Plantago major L., Persicaria lapathifolia (L.) Gray, Veronica spp. L., and Vicia cracca $\mathrm{L}$. were the most abundant newcomers when comparing the recorded weed species in 2017 with the original weed observations in 2015. A scanty winter wheat stand, with only 333 crop ears $\mathrm{m}^{-2}$ in midAugust 2016, favored the occurrence of winter annual T. inodorum, which was also one of the most abundant species in terms of density, but not of biomass, in spring wheat in 2017 (Fig. 5).

The number of observed weed species was higher in RT but the diversity of weed population was higher in
2016

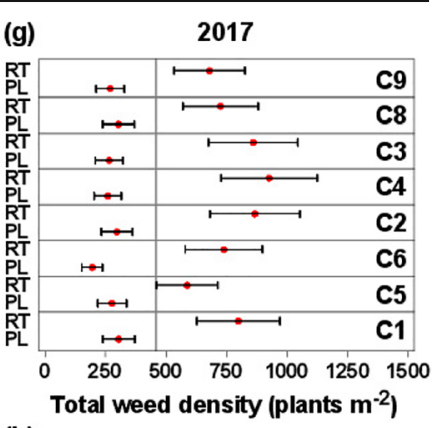

(h)

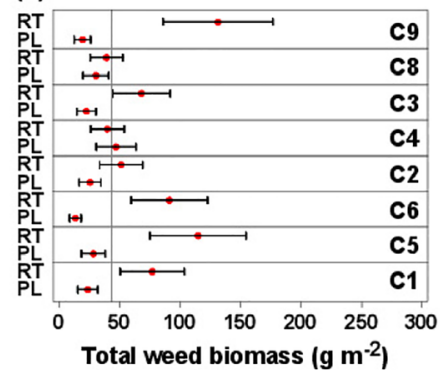

(i)

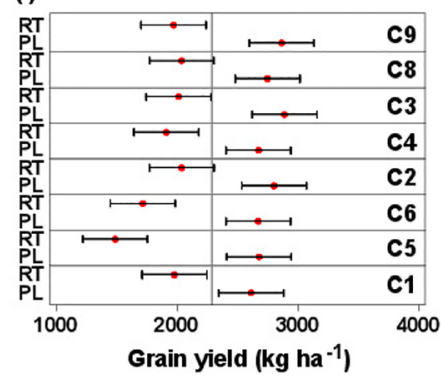

the Weeds area. The vertical reference lines denote the overall means in each year. Statistically significant $(P<0.05)$ differences for pairwise comparisons of the CC treatments with $\mathrm{C} 1$ (no CCs) are denoted by asterisks. In 2016-2017 (d-i), the CC treatments were compared through the averages of the means of the two tillage systems

PL as indicated by diversity indices (Fig. 5). RT favored the proliferation of $S$. media, Galium spurium L., and $M$. arvensis in terms of weed density (data not shown). In contrast, T. inodorum and $V$. arvensis thrived in PL. As regards the weed biomass in 2017, evident differences in proportions of weed species were detected between the tillage systems for instance in case of C. arvense, T. inodorum, and Taraxacum spp. (Fig. 5).

Crop growth and yield

There were some environmental challenges in conducting the field experiment. Namely, spring barley suffered from extremely cool and rainy weather in 2015 , 
Table 5 Test results of the fixed main and interaction effects in the linear mixed models for the weed density and biomass and for the crop yield (statistically significant $P$ values are in italics)

\begin{tabular}{|c|c|c|c|c|c|c|c|c|c|c|}
\hline \multirow[t]{2}{*}{ Year } & \multirow[t]{2}{*}{ Effect } & \multicolumn{3}{|c|}{ Weed density } & \multicolumn{3}{|c|}{ Weed biomass } & \multicolumn{3}{|c|}{ Crop yield } \\
\hline & & $F$ value & d.f. & $P$ value & $F$ value & d.f. & $P$ value & $F$ value & d.f. & $P$ value \\
\hline \multirow[t]{2}{*}{2015} & Cover crop, Weeds ${ }^{\mathrm{a}}$ & 0.67 & 5,15 & 0.65 & 0.46 & 5,15 & 0.80 & 3.87 & 8,24 & $<0.005$ \\
\hline & Cover crop, BRSRO & 0.48 & 5,18 & 0.79 & 1.22 & 5,18 & 0.34 & - & - & - \\
\hline \multirow[t]{4}{*}{2016} & Cover crop & 6.36 & 8,25 & $<0.001$ & 5.65 & 8,50 & $<0.001$ & 1.60 & 8,24 & 0.18 \\
\hline & Tillage & 0.67 & 1,5 & 0.45 & 17.44 & 1,50 & $<0.001$ & 0.49 & 1,3 & 0.53 \\
\hline & Cover crop $\times$ tillage & 2.41 & 8,25 & $0.04^{\mathrm{b}}$ & 1.13 & 8,50 & 0.36 & 0.63 & 8,23 & 0.75 \\
\hline & Crop cover (covar.) & - & - & - & 5.82 & 1,40 & 0.02 & 5.85 & 1,41 & 0.02 \\
\hline \multirow[t]{3}{*}{2017} & Cover crop & 1.16 & 8,48 & 0.34 & 0.70 & 8,24 & 0.69 & 1.88 & 8,48 & 0.08 \\
\hline & Tillage & 40.74 & 1,3 & 0.01 & 38.29 & 1,27 & $<0.001$ & 7.72 & 1,6 & 0.03 \\
\hline & Cover crop $\times$ tillage & 1.13 & 8,48 & 0.36 & 2.40 & 8,27 & 0.04 & 0.92 & 8,48 & 0.51 \\
\hline
\end{tabular}

${ }^{\mathrm{a}}$ In 2015, weed density and biomass were assessed both from areas with natural weed infestation (Weeds) and from areas with natural weeds and additionally sown oilseed weed (BRSRO)

${ }^{\mathrm{b}}$ By removing one marked outlier observation, the interaction effect was not significant $(P=0.13)$

leading to delayed early growth and a harvest delayed until the end of August. Consequently, there was only a 1-week free growth period for CCs, instead of the planned 3-4 weeks, between the barley harvest and primary tillage for the winter wheat seedbed.

The overwintering of winter wheat was only moderate, resulting in a relatively sparse wheat stand, with an average crop cover of $44 \%$ at the end of May 2016, which was reflected in both weed suppression ability and crop yield. Furthermore, the early growth of spring wheat in 2017 was slow, particularly in RT plots, because of cool wet weather in June (Table 3). Thus, none of the cereals in rotation were highly competitive against CCs and weeds. Nevertheless, most (75-95\%) total above-ground biomass was produced by the crop in all years and treatments.

In 2015 , the crop density at harvest time averaged 447 ears $\mathrm{m}^{-2}$ and the barley yield without CCs (C1) was $3432 \pm 337 \mathrm{~kg} \mathrm{ha}^{-1}$ (Fig. 3c). Winter rye as CC (C5) was the only treatment that significantly reduced the crop yield, on average by $1249 \mathrm{~kg} \mathrm{ha}^{-1}$, compared with $\mathrm{C} 1$ (Fig. 3c). Likewise, the crop yield averaged across the

Table 6 Differences in weed abundance and crop yield between the tillage systems ( $R T$, reduced; $P L$, plowed) and their dependences on cover crop type. Statistically significant $P$ values are in italics. The number of observations is 4 in $C 5$ and C6, 20 in legumes, and 36 overall

\begin{tabular}{|c|c|c|c|c|c|c|c|c|c|}
\hline \multirow[t]{3}{*}{ Year } & \multirow[t]{3}{*}{ Cover crop type } & \multicolumn{4}{|c|}{ Weed biomass } & \multicolumn{4}{|l|}{ Grain yield } \\
\hline & & \multicolumn{2}{|c|}{ Mean \pm SEM $\left(D M g^{-2}\right)$} & \multirow{2}{*}{$\begin{array}{l}\text { Difference } \\
\text { RT vs. PL (\%) }\end{array}$} & \multirow[t]{2}{*}{$P$} & \multicolumn{2}{|c|}{ Mean \pm SEM $\left(\mathrm{kg} \mathrm{ha}^{-1}\right)$} & \multirow{2}{*}{$\begin{array}{l}\text { Difference } \\
\text { RT vs. PL }\left(\mathrm{kg} \mathrm{ha}^{-1}\right)\end{array}$} & \multirow[t]{2}{*}{$P$} \\
\hline & & $\mathrm{RT}$ & PL & & & RT & PL & & \\
\hline \multirow[t]{4}{*}{2016} & Non-legume (C5) & $79 \pm 22.6$ & $74 \pm 21.2$ & $+7^{\mathrm{a}}$ & 0.87 & $2505 \pm 119$ & $2634 \pm 119$ & -128 & 0.32 \\
\hline & Mixed (C6) & $50 \pm 14.3$ & $110 \pm 31.6$ & -55 & 0.04 & $2674 \pm 119$ & $2659 \pm 119$ & +14 & 0.91 \\
\hline & Legumes & $27 \pm 4.2$ & $54 \pm 8.3$ & -49 & $<0.001$ & $2725 \pm 77$ & $2754 \pm 77$ & -29 & 0.70 \\
\hline & Overall & $41 \pm 5.4$ & $70 \pm 9.3$ & -42 & $<0.001$ & $2646 \pm 71$ & $2690 \pm 71$ & -44 & 0.53 \\
\hline \multirow[t]{4}{*}{2017} & Non-legume (C5) & $115 \pm 39.7$ & $28 \pm 9.8$ & +304 & 0.01 & $1488 \pm 267$ & $2677 \pm 267$ & -1189 & 0.01 \\
\hline & Mixed (C6) & $91 \pm 31.5$ & $14 \pm 4.7$ & +563 & $<0.001$ & $1716 \pm 267$ & $2669 \pm 267$ & -953 & 0.03 \\
\hline & Legumes & $59 \pm 9.8$ & $28 \pm 4.6$ & +113 & $<0.005$ & $1993 \pm 230$ & $2793 \pm 230$ & -800 & 0.05 \\
\hline & Overall & $71 \pm 9.3$ & $27 \pm 3.6$ & +162 & $<0.001$ & $1845 \pm 226$ & $2734 \pm 226$ & -888 & 0.03 \\
\hline
\end{tabular}

\footnotetext{
${ }^{\text {a }}$ For the non-leguminous cover crop (C5), the mean weed biomass was 7\% higher in RT plots than in PL plots
} 
Fig. 4 Effect of primary tillage on the biomass fraction of weeds with different life forms. Weed infestation in spring wheat 2017 pooled over the CC treatments. The actual total dry weight of weeds averaged $71 \mathrm{~g} \mathrm{~m}^{-2}$ in reduced tillage and $27 \mathrm{~g} \mathrm{~m}^{-2}$ in plowed plots, respectively

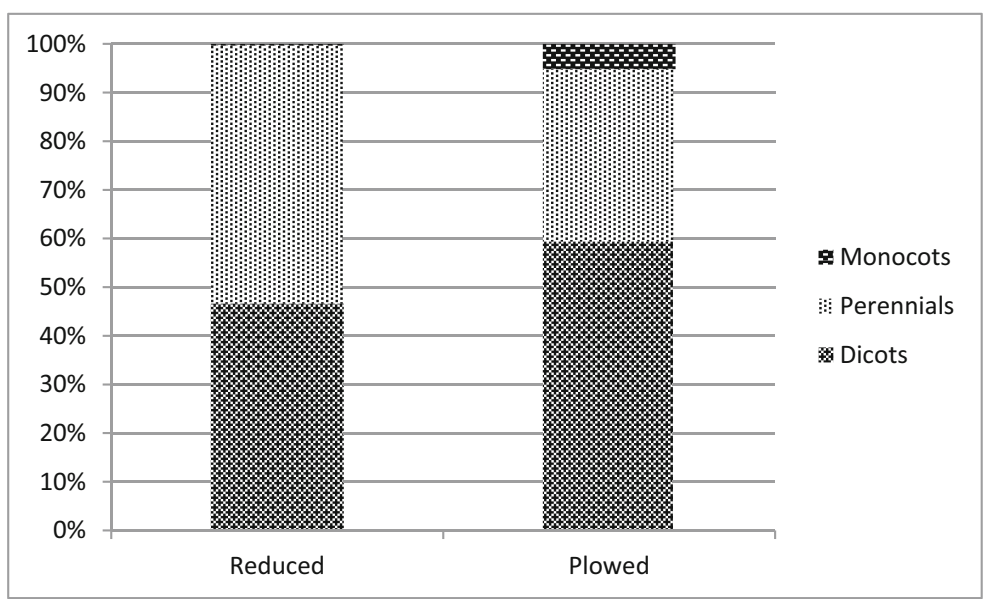

treatments with leguminous CCs was $918 \mathrm{~kg} \mathrm{ha}^{-1}$ greater $(P<0.001)$ than in $\mathrm{C} 5$.

In 2016, the winter wheat yield in PL was at the same level as in RT (Table 6). Furthermore, no statistically significant yield differences among the $\mathrm{CC}$ treatments were detected nor dependence of the effect of tillage treatment on $\mathrm{CC}$ treatment (Tables 5 and 6 , Fig. 3f).

After 2 years with different tillage practices, the yield differences between PL and RT became apparent in 2017 (Table 6), but no statistically significant differences among the individual CC treatments were detected (Table 5, Fig. 3i). However, the crop yield averaged across the tillage systems was $311 \mathrm{~kg} \mathrm{ha}^{-1}$ greater $(P=$ $0.01)$ after leguminous CCs than in the plots where nonleguminous CCs (C5) had been grown. Moreover, the yield difference of spring wheat between RT and PL tended to be smaller after leguminous CCs than in $\mathrm{C} 5$ (Table 6).

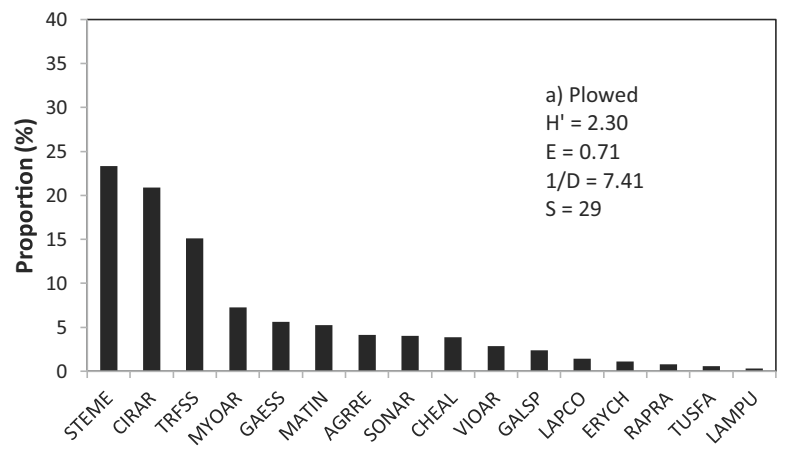

Fig. 5 Comparison of weed diversity between plowed plots (a) and reduced tillage (b) using Shannon index for diversity $\left(\mathrm{H}^{\prime}\right)$ and evenness (E) and Simpson's index for dominance (D) calculated using biomass values for a total number of observed weed species

\section{Discussion}

In this study, we explored the possibilities for reducing primary tillage in organic cereal cropping without jeopardizing crop yield due to increasing weed infestation. In addition to relying on crop competiveness against weeds, we introduced tailored CC treatments to suppress weed growth complementarily, recognizing that weed management is one of the key challenges if fields are not plowed (Melander et al. 2013; Zikeli and Gruber 2017).

Weed response to tillage

Unfortunately, the achieved outcome was not encouraging because after 2 years with RT, the weed species composition shifted towards highly competitive perennial species like $C$. arvense, whereas annual dicot species dominated the weed population in PL. Moreover,

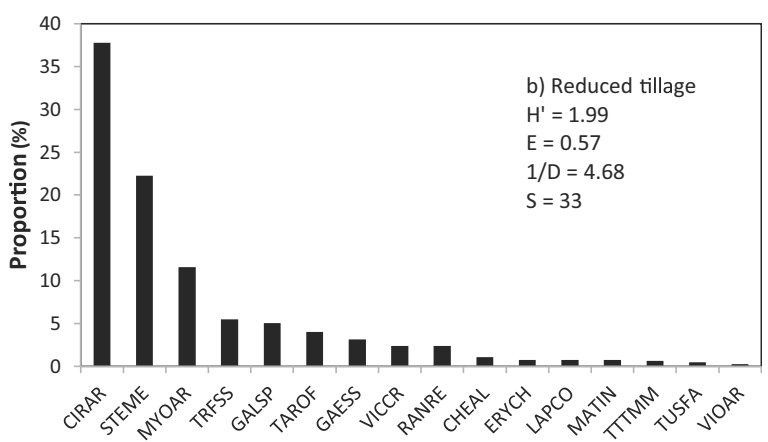

(S). Biomass shares of the 16 most abundant species in spring wheat in 2017 are presented. EPPO codes for weed species available at: https:/gd.eppo.int/ 
Taraxacum spp. thrived in RT, as reported also by Gill and Arshad (1995). One of the potential RT-promoted species, couch grass (Elymus repens (L.) Gould), was not abundant in the experimental field. In addition to perennial species, RT favored some dicot species such as $M$. arvensis and $S$. media. Moreover, white sweet clover, sown as a CC, remained a serious volunteer weed in RT in 2017.

After the first year of RT, there were no yield differences compared with PL. In contrast, after the second year, a 30\% lower spring wheat yield in RT was recorded. In practice, weeds were not the only variable that contributed to the yield difference, but the crop in RT suffered more from wet conditions than in PL. Wheat evidently suffered from low soil temperature, which is typical in RT systems (Vakali et al. 2011). The weak crop stand in RT was naturally a poor competitor against weeds, resulting in high weed biomass production. The confounding factors affecting weed occurrence, and consequently crop yield, were demonstrated in earlier studies (e.g., Benaragama et al. 2016; Woźniak and Soroka 2018).

Previous studies and farmers' experiences have demonstrated that RT systems favor annual grass weeds (Scherner et al. 2016) and perennial weed species (Thomas et al. 2004; Tørresen et al. 2003; Armengot et al. 2015). However, stubble tillage should be regarded as a potential option in organic cropping if it can be repeated during autumn or combined with other weed management practices such as plowing and inclusion of forage crops for mowing in the crop rotation (Lukashyk et al. 2008; Brandsæter et al. 2017). In Finland, the short growing season normally allows only a single stubble treatment in autumn and plowing of heavy clay soils in spring is not feasible for obtaining a proper seedbed soil structure. In this experiment, both RT and PL areas had to be plowed in the autumn 2014 to properly terminate the preceding grass-clover stand.

\section{Weed suppression with cover crops}

Rapid CC establishment and early development resulting in a dense but low canopy and high soil coverage should lead to effective weed suppression in the field (Dorn et al. 2015). The hypothesis in the present study was that the best CC mixtures, with relatively high seeding rates, would efficiently compete against weeds and thus reduce weed biomass. This was not fully achieved with the $\mathrm{CC}$ treatments in spring barley in
2015. It is questionable to recommend CCs as a oneseason weed management option in spring cereals given that the majority of harmful weeds in spring cereal fields in Finland are annual dicot species (Salonen et al. 2011). CCs simply were too slow to hamper the growth of early emerging tall weed species like Galeopsis spp. and the supplemental weed, oilseed turnip rape, effectively. Statistically non-significant differences in weed growth among CC treatments can be due to the size of rectangular frame and the small number of replicates and should therefore be treated cautiously.

In Finland, CCs are often sown in connection with weed harrowing, at the latest at the 3-4 leaf stage of spring cereals, to limit their unwanted competition against the crop. However, in Swedish experiments (Ohlander et al. 1996), CC sowing at the 3-leaf stage of spring barley resulted in yield decrease probably as a result of mechanical damage to barley plants caused by drilling. In order to enhance competition against weeds, CCs in the present study were sown 1 day after the main crop. Brandsæter et al. (2012) applied the same strategy with undersown clover against perennial weeds, but failed to reduce the weed biomass production significantly. This corresponds with our findings with annual dicot weeds in spring cereals.

An ideal CC for weed suppression needs to be reliable in a variety of cropping conditions. Italian ryegrass, one of the most popular CCs in Finland (Alestalo 2016), proved to be sensitive to environmental conditions and to competition from the crop. Therefore, it should be sown preferably in mixtures to gain more consistent biomass production across sites and over years. Red clover and white clover could be the most ideal mixture partners, in contrast to taller clovers $T$. incarnatum and T. resupinatum at early sowing. The large variability observed among clover species indicates that selection of species and their varieties is an important aspect when introducing CCs (Hollander et al. 2007).

Considering biological diversity, in addition to introducing CC plant species in cereal stands, we succeeded in increasing the number of weed species to some extent during the experimental period with cereal rotation. Increased diversity should be viewed as an indicator of sustainability because a more diverse weed community can be less competitive against the crop (Storkey and Neve 2018). All weed species identified in the experimental field were typical of Finnish cereal fields (Salonen et al. 2011). As a consequence of increased infestation of $C$. arvense in RT, the total weed biomass 
was higher in RT than in PL. The dominance of C. arvense biomass in RT resulted also in lower weed diversity than in PL.

The undersown CC treatments did not result in any marked penalty in cereal yields, except in spring barley with undersown rye. In 2017, repeated growing of leguminous CCs subsequently resulted in a higher average yield of spring wheat and a smaller difference in weed biomass between tillage treatments compared with non-leguminous CC treatment (C5). This is in line with the meta-analysis reported by Verret et al. (2017), indicating that the use of legume companion plants generally enhanced weed control without reducing crop yield.

\section{Conclusions}

In this study, we demonstrated that undersown CCs had a limited potential in keeping weed occurrence in cereal rotations down to acceptable levels, particularly in reduced tillage systems which promoted perennial weed species. In sparse cereal stands, CCs can compensate for the reduced competitive ability of the crop against weeds. In general, CCs should be regarded as a feasible option in organic cropping because they may conserve soil nutrients, increase soil organic matter, and increase plant diversity without substantially reducing cereal yields.

Future research in long-term field experiments should focus on the potential of undersown CCs to suppress weed growth during the latter part of the growing season, including the period between crop harvest and tillage. Effects of CCs on weed seed production, emergence of winter annual weeds, and responses of perennial weeds to $\mathrm{CC}$ competition should be further investigated.

Timing of CC termination and combination with other weed control measures is of great interest, particularly in the northern latitudes with a limited control period. In summary, CCs should be regarded as an integral component among other cultural practices that aims at optimizing the entire cropping system, thereby facilitating weed management, as suggested by Bàrberi (2001).

Undersown CCs should ideally combine adequate weed suppression with marginal negative effects on crop growth and yield. Further research and extension efforts are required to ensure that $\mathrm{CCs}$, as integrated weed management measures, are sufficiently biologically, economically, and environmentally robust to facilitate greater adoption at the farm level. Currently, agri-environmental support of $100 € \mathrm{ha}^{-1}$ is granted for CCs growing in Finland, thus providing a good economic incentive for promoting $\mathrm{CC}$ use.

Acknowledgments This study was carried out within the framework of the PRODIVA project funded by the ERA-NET Core Organic Plus action (www.coreorganicplus.org), receiving national funding from the MAKERA research grant. Extra finance was granted by the Research Foundation on Organic Production (www.luomusaatio.fi). Expert advice on cover crop species from Dr. Hannu Känkänen/Natural Resources Institute Finland (Luke) and Timo Mäkinen/Naturcom Oy is warmly acknowledged.

Funding Information Open access funding provided by Natural Resources Institute Finland (LUKE).

Open Access This article is distributed under the terms of the Creative Commons Attribution 4.0 International License (http:// creativecommons.org/licenses/by/4.0/), which permits unrestricted use, distribution, and reproduction in any medium, provided you give appropriate credit to the original author(s) and the source, provide a link to the Creative Commons license, and indicate if changes were made.

\section{References}

Alestalo L (2016) Kerääjäkasvien viljely Uudellamaalla vuonna 2015. Uudenmaan ELY-keskus, Raportteja 25/2016, 28 p. (available in Finnish at: www.doria.fi/ely-keskus). Accessed 9 July 2019

Andert S, Bürger J, Stein S, Gerowitt B (2016) The influence of crop sequence on fungicide and herbicide use intensities in North German arable farming. Eur J Agron 77:81-89

Armengot L, Berner A, Blanco-Moreno J, Mäder P, Sans XJ (2015) Long-term feasibility of reduced tillage in organic farming. Agron Sustain Dev 35:339-346

Armengot L, Blanco-Moreno JM, Barberi P, Bocci G, Carlesi S, Aendekerk R, Berner A, Celette F, Grosse M, Huiting H, Kranzler A, Luik A, Mäder P, Peigne J, Stoll E, Delfosse P, Sukkel W, Surböck A, Westaway S, Sans FX (2016) Tillage as a driver of change in weed communities: a functional perspective. Agric Ecosyst Environ 222:276-285

Aronsson H, Ringselle B, Andersson L, Bergkvist G (2015) Combining mechanical control of couch grass (Elymus repens L.) with reduced tillage in early autumn and cover crops to decrease nitrogen and phosphorus leaching. Nutr Cycl Agroecosyst 102:383-396

Askegaard M, Olesen JE, Kristensen K (2005) Nitrate leaching from organic arable crop rotations: effects of location, manure and catch crop. Soil Use Manag 21:181-188

Bàrberi P (2001) Weed management in organic agriculture: are we addressing the right issues? Weed Res 42:177-193

Benaragama D, Shirtliffe SJ, Johnson EN, Duddu HSN, Syrovy LD (2016) Does yield loss due to weed competition differ 
between organic and conventional cropping systems? Weed Res 56:274-283

Bergkvist G, Adler A, Hansson M, Weih M (2010) Red fescue undersown in winter wheat suppresses Elytrigia repens. Weed Res 50:447-455

Brandsæter LO, Thomsen MG, Wærnhus K, Fykse H (2012) Effects of repeated clover undersowing in spring cereals and stubble treatments in autumn on Elymus repens, Sonchus arvensis and Cirsium arvense. Crop Prot 32:104110

Brandsæter LO, Mangerud K, Helgheim M, Berge TW (2017) Control of perennial weeds in spring cereals through stubble cultivation and mouldboard ploughing during autumn or spring. Crop Prot 98:16-23

Carr PM, Gramig GG, Liebig MA (2013) Impacts of organic zero tillage systems on crops, weeds and soil quality. Sustainabilty 5:3171-3201

Casagrande M, Peigne J, Payet V, Mäder P, Sans XF, BlancoMoreno JM, Antichi D, Barberi P, Beeckmann A, Bigongiali F, Cooper J, Dierauer H, Gascoyne K, Grosse M, Heß J, Kranzler A, Luik A, Peetsmann E, Surböck A, Willekens K, David C (2016) Organic farmers' motivations and challenges for adopting conservation agriculture in Europe. Org Agric 6: 281-295

Cooper J, Baranski M, Stewart G, Nobel-de Lange M, Barberi P, Fliessbach A, Peigne J, Berner A, Brock C, Casagrande M, Crowley O, David C, De Vliegher A, Döring TF, Dupont A, Entz M, Grosse M, Haase T, Halde C, Hammerl V, Huiting H, Leithold G, Messmer M, Schloter M, Sukkel W, van der Heijden MGA, Willekens K, Wittwer R, Mäder P (2016) Shallow non-inversion tillage in organic farming maintains crop yields and increases soil C stocks: a meta-analysis. Agron Sustain Dev 36:1-22

Doltra J, Olesen J (2013) The role of catch crops in the ecological intensification of spring cereals in organic farming under Nordic climate. Eur J Agron 44:98-108

Dorn B, Jossi W, van der Heijden MG (2015) Weed suppression by cover crops: comparative on-farm experiments under integrated and organic conservation tillage. Weed Res 55: 588-597

Gbur EE, Stroup WW, McCarter KS, Durham S, Young LJ, Christman M, West M, Kramer M (2012) Analysis of generalized linear mixed models in the agricultural and natural resources sciences. American Society of Agronomy, Madison $298 \mathrm{p}$

Gill KS, Arshad MA (1995) Weed flora in the early growth period of spring crops under conventional, reduced, and zero tillage systems on a clay soil in northern Alberta, Canada. Soil Tillage Res 33:65-79

Gomez KA, Gomez AA (1984) Statistical procedures for agricultural research, 2nd edn. John Wiley and Sons, New York, 680 $\mathrm{p}$

Gruber S, Claupein W (2009) Effect of tillage intensity on weed infestation in organic farming. Soil Tillage Res 105:104-111

Håkansson S (2003) Weeds and weed management on arable land: an ecological approach. CABI Publishing, UK 274 p

Hollander NG, Bastiaans L, Kropff MJ (2007) Clover as a cover crop for weed suppression in an intercropping design. I. Characteristics of several clover species. Eur J Agron 26: 92-103
Kenward MG, Roger JH (1997) Small sample inference for fixed effects from restricted maximum likelihood. Biometrics 53: 983-997

Kolb LN, Gallandt ER (2012) Weed management in organic cereals: advances and opportunities. Org Agric 2:23-42

Kruidhof HM, Bastiaans L, Kropff MJ (2007) Ecological weed management by cover cropping: effects on weed growth in autumn and weed establishment in spring. Weed Res 48:492502

Lukashyk P, Berg M, Kopke U (2008) Strategies to control Canada thistle (Cirsium arvense) under organic farming conditions. Renewable Agric Food Syst 23:13-18

Luke (2019) Luke's statistical services at https://stat.luke.fi/en. Accessed 5 April 2019

Magurran AE (1988) Ecological diversity and its measurement. Princeton University Press, USA $179 \mathrm{p}$

Melander B (2018) PRODIVA project web-site: http://projects.au. $\mathrm{dk} /$ coreorganicplus/research-projects/prodiva/ Accessed 14 May 2019

Melander B, Munier-Jolan N, Charles R, Wirth J, Schwarz J, Weide R, Bonin L, Jensen PK, Kudsk P (2013) European perspectives on the adoption of nonchemical weed management in reduced-tillage systems for arable crops. Weed Technol 27:231-240

Ohlander L, Bergkvist G, Stendahl F, Kvist M (1996) Yield of catch crops and spring barley as affected by time of undersowing. Acta Agric Scand Sect B Soil Plant Sci 46: 161-168

Olesen JE, Hansen EM, Askegaard M, Rasmussen IA (2007) The value of catch crops and organic manures for spring barley in organic arable farming. Field Crop Res 100:168-178

Peigne J, Ball BC, Roger-Estrade J, David C (2007) Is conservation tillage suitable for organic farming? A review. Soil Use Manag 23:129-144

Reiss A, Fomsgaard IS, Mathiassen SK, Kudsk P (2018) Weed suppressive traits of winter cereals: allelopathy and competition. Biochem Syst Ecol 76:35-41

Salonen J, Hyvönen T, Jalli H (2011) Composition of weed flora in spring cereal fields in Finland - a fourth survey. Agric Food Sci 20:245-261

Salonen J, Hyvönen T, Kaseva J, Jalli H (2012) Impact of changed cropping practices on weed occurrence in spring cereals in Finland - a comparison of surveys in 1997-1999 and 20072009. Weed Res 53:110-120

Salonen J, Koppelmäki K, Känkänen H (2017) Weed management with cover crops in the Nordic-Baltic region - a snapshot of the references. http://projects.au.dk/fileadmin/PRODIVA CoverCrop_review2017_final.pdf. Accessed 14 May 2019

SAS Institute Inc (2016) SAS/STAT® 14.2 user's guide. SAS Institute Inc., Cary

Scherner A, Melander B, Kudsk P (2016) Vertical distribution and composition of weed seeds within the plough layer after eleven years of contrasting crop rotation and tillage systems. Soil Tillage Res 161:135-142

Storkey J, Neve P (2018) What good is weed diversity? Weed Res 58:239-243

Sturm DJ, Peteinatos G, Gerhards R (2018) Contribution of allelopathic effects to the overall weed suppression by different cover crops. Weed Res 58:331-337

Thomas AG, Derksen DA, Blackshaw RE, van Acker RC, Legere A, Watson PR, Turnbull GC (2004) A multistudy approach to 
understanding weed population shifts in medium- to longterm tillage systems. Weed Sci 52:874-880

Tørresen KS, Skuterud R, Tandsæther HJ, Hagemo MB (2003) Long-term experiments with reduced tillage in spring cereals. I. Effects on weed flora, weed seedbank and grain yield. Crop Prot 22:185-200

Turner RJ, Davies G, Moore H, Grundy AC, Mead A (2007) Organic weed management; a review of the current UK farmer perspective. Crop Prot 26:377-382

Vakali C, Zaller JG, Köpke U (2011) Reduced tillage effects on soil properties and growth of cereals and associated weeds under organic farming. Soil Tillage Res 111:133-141

Verret V, Gardarin A, Pelzer E, Mediene S, Makowski D (2017) Can legume companion plants control weeds without decreasing crop yield? A meta-analysis. Field Crop Res 204:158-168

Woźniak A, Soroka M (2018) Effect of crop rotation and tillage system on the weed infestation and yield of spring wheat and on soil properties. Appl Ecol Environ Res 16:3087-3096

Zikeli S, Gruber S (2017) Reduced tillage and no-till organic farming systems, Germany - status quo, potentials and challenges. Agric 7(4):35. https://doi.org/10.3390 /agriculture 7040035

Publisher's note Springer Nature remains neutral with regard to jurisdictional claims in published maps and institutional affiliations. 